\title{
Supply Management Assistance IN "FAEYZA Seamtress" Sewing Business
}

\author{
Fetri Setyo Liyundira \\ Departement of Accountinng, STIE Widya Gama Lumajang, Indonesia \\ Email: liyundira90@gmail.com
}

\begin{tabular}{lll}
\hline Submission : & Review : & Publication : \\
$1^{\text {st }}$ April 2020 & $13^{\text {th }}$ June 2020 & $28^{\text {th }}$ Augustu 2020 \\
\hline
\end{tabular}

\begin{abstract}
Abstrak
The transaction process of a trading company includes a calculation of the cost of good sold because it contains an inventory of merchandise, so the company needs to specifically record every transaction related to this inventory, and in its development it is still experiencing various problems. The approach method offered to solve partner problems consists of: surveys, interviews, knowledge of inventory methods, recording of inventory methods, assistance and equipment, monitoring and evaluation. This Community Service activity is expected to provide a computerized recording system for inventory methods and the procurement of adequate equipment to support the sewing process.
\end{abstract}

\section{Keywords: Cost of Good Sold, Inventory Method Recording}

\section{INTRODUCTION}

Facing an era of increasingly fierce competition, a person is required to have a high entrepreneurial spirit so that he can run the business he is doing well. Thus we must be able to see market opportunities and desires in terms of needs and the selling value that we will offer to consumers. As the company grows, the need for planning is even greater. Time cannot be saved, time must be used wisely. The right mental attitude towards work is very important. Successful entrepreneurs enjoy their jobs and are totally dedicated to what they do.

Their positive mental attitude turns their job into one that is exciting, attractive and fulfilling. Entrepreneurs need to manage their time effectively, and the key to using that time lies in better management. Being entrepreneurial means having the ability to find and evaluate opportunities, gather the necessary resources and act to take advantage of those opportunities. Entrepreneurs should spend most of their time planning business activities. Departing from these things, an entrepreneur is required to be able to manage or control his personal attitude correctly. In running a business (entrepreneurship), a business actor must have: 1. Skill (ability) A business actor must have the skill (ability) to do entrepreneurship because without the skill (ability) a business actor will not be able to do entrepreneurship. So skill (ability) is the main asset that must be owned in entrepreneurship. 2. Determination (will) If a business actor already has the skills (ability) but without the determination (strong will) to entrepreneurship, the entrepreneurial skills will be in vain because they cannot be channeled. So basically skills and determination must be possessed by an entrepreneur. 3. Capital Capital is a very supportive aspect of starting and running a business besides having the skills and determination. 4. Targets and Objectives $\mathrm{A}$ business actor, if he wants to run a business, must be able to determine the target and marketing objectives. Because if the targets and goals are not planned, the business that is carried out may not last long. 5. Place The place of entrepreneurship is an aspect that must be 
owned if you want to run entrepreneurship. Because the place is also very supportive in terms of entrepreneurship and can make a consideration by consumers regarding the entrepreneurship that is being carried out. Today, running a garment sewing service entrepreneur is still promising. Even though there are now a lot of ready-made clothing products, consumers still need sewing services. Because there are several risks of buying finished clothes that are usually accepted by buyers. Apparel is usually made in standard sizes (S, M, L, and XL). Although the models and materials are quite varied and the price is cheaper than wearing a tailor, not all finished clothes are suitable for consumers. Especially for people who have a posture that is different from the standard of people in general, such as too small or too fat. Sewing services will still be hunted by people like this. Besides that, there are certain styles and materials of clothing that are more comfortable when worn from ordinary stitches, rather than in the form of factory-produced garments. For example, traditional clothes, lace fabrics, suits, kebaya, woven fabrics and others. This service partner is women in East Sidorame Village, Medan Perjuangan District, Medan City who opens a clothing sewing service business. Partners actually specialize in sewing services for kebaya clothes, but sometimes accept other clothing stitches such as skirts, shirts, pants and other clothes. They still have limited tools, only sewing machines. For grinding and embroidering, you still have to pay it to another shop, so it requires a longer production time. This makes them less efficient at work. Besides, the opportunity to get a bigger profit is lost.

Companies engaged in trade and services need to record accounting to determine the financial condition of their business. Because the resulting financial statements will be able to show the company's actual financial condition, profit or loss. The trading company transaction process includes the calculation of the cost of good sold because there is an inventory of merchandise in it, so the company needs to record specifically every transaction related to the inventory. According to Harnanto (2002), inventories are all goods that are owned for the purpose of reselling or consumption in the company's normal operations.

A trading company obtains inventory by purchasing finished goods that are ready to be resold immediately. Meanwhile, manufacturing companies get supplies by producing themselves. So that manufacturing companies will incur production costs such as raw material costs, direct labor costs, and factory overhead costs .For trading companies whose business is to buy and resell merchandise, inventory is generally classified into 2, namely:

1. Merchandise inventory, these items will not physically change until the goods are sold.

2. Other inventories, these items are used for a short period of time and are usually charged as general and administrative expenses or usually as marketing expenses.

Sme Business Stitches "FAEYZA Seamtress" Beautiful is a business services that accept clothing sewing service men and women are addressed in the hamlet Sido Mulyo Gucialit Village district. Sukodono Kab. Lumajang, although it has been running for about 5 years, it turns out that this service business still has not implemented records that are in accordance with accounting standards.

The process of recording inventory is indeed not easy, but it is very important to be used and implemented by all business actors to make it easier for us to control merchandise so that there is no fraud and can be detected as early as possible. This inventory recording can also make it easier for business actors to know the entry and exit of goods so that there is no longer running out of merchandise when the buyer needs it.

There are several methods for recording merchandise inventory in accounting, depending on the business actor who will use and apply it with due regard to the expected profit or profit later. After we know how important it is for small and large companies to 
record inventory, because it will have an impact on the profits we get in the process of selling goods in accordance with the accounting cycle.

\section{IMPLEMENTATION METHODS}

From the above problems, there are several solutions that are offered through the following stages: (1) The first stage: conducting a survey of partners to see the conditions and situation of the partners' business, (2) The second stage: conducting interviews with partners in order to explore various business problems and obtain various information related to the business, (3) The third stage: introduction of the merchandise inventory method, (4) The fourth stage: assistance in the procurement of equipment to expedite the process of making finished clothes, (5) The fifth stage: monitoring and evaluation.

The approach method offered to solve partner problems consists of the following steps: (1) Survey: this activity will be carried out to see the situation and condition of the partner's business, (2) Interview: the purpose of this interview is to gather information on partner problems and at the same time find solutions, (3) Knowledge of inventory methods: this implementation will be carried out by the lecturer, namely the delivery of material about supplies to business owners and employees of the inventory department, (4) Inventory method recording: this implementation will be accompanied by the lecturer to determine what method is most suitable and suitable for partner business so that the recording is well structured, (5)Equipment assistance: equipment assistance is used to support sewing activities to produce raw materials into finished materials, (6)Monitoring and evaluation: monitoring and evaluation activities are carried out periodically until partners can produce inventory reports properly and the output of this program can be achieved, starting with the application of the accounting method used in accordance with what has not been submitted. Utilization of the use of equipped equipment is expected to support partner production activities to produce more sewing services so that the profit generated is also large and consumers are satisfied.

\section{RESULTS AND DISCUSSION}

The measure of the success of the Community Service program for business groups in the field of home industry in the village of Gucialit, Lumajang Regency is by achieving the target of this activity, while this target is an increase in the quality of stitches, increased consumer interest, recording methods of inventory, the existence of structured recording with using one of the methods according to Accounting. This Community Service Activity is expected to provide output for partners, namely a computerized inventory method recording system and the procurement of adequate equipment to support the sewing process .

Initial preparation before conducting interviews with business actors is carried out with the aim of seeing the initial conditions of the business that have been running. This activity also aims to prepare community service programs, and aims to collect businessrelated data and information. The survey activity was carried out on February 5, 2019, the findings of the survey found that the conditions for sewing were still very minimal, the supplies of sewing equipment were also not neatly arranged, the inventory records were still not going well, it was proven that some of the supplies were not included in the inventory of goods, when the goods it disappeared also could not be detected.

$\mathrm{P}$ there is a FIFO method the first item purchased is the first item to be sold. This method corresponds to the actual cost flow (cash flow ). FIFO method is the method most commonly used in inventory valuation. In the FIFO method, the value of goods that will go out for production activities is based on the price that was first entered. So that the final 
goods inventory using a price based on the new price or the price with the last order purchased. Therefore, the FIFO method is more visible in calculating the COGS . The cost used to purchase the first item is the Cost Of Good Sold (COGS). The selling price calculation is based on the price of the previous transaction stock of goods.

The availability of sufficient and quality information will make it easier and faster for management to make decisions, it is necessary to distribute computerized information so that the information provided is more accurate, efficient and effective in realizing the goals of the company when compared to manual data processing. By creating an application program that uses Visual Basic 6.0 programming will assist in systemized data processing.

\section{CONCLUSION}

The community service program is running well and smoothly, mentoring has been proposed to succeed in making a reporting and recording of supplies. This activity received full support from the trading business group, because the results provided new ideas in terms of accounting records.

\section{REFERENCES}

Martani, Dwi., (2012). Akuntansi Keuangan Menengah Berbasis PSAK. Jakarta: Salemba Empat.

Retna, Erna., (2015). IbM Usaha Jahitan dan Pengelolaan Kain Perca. Jurnal Dedikasi, ISSN 1693-3214 Vol. 12, Mei 2015.

Thomas W dan Norman M., (1998). Pengantar Kewirausahaan dan Manajemen Bisnis Kecil. Prenhallindo: Jakarta 